IJMS 23 (2), 27-44 (2016)

\title{
PETROLEUM CONSUMPTION AND FINANCIAL DEVELOPMENT IN MALAYSIA
}

\author{
JEN-EEM CHEN \\ Fakulti Pengurusan Perniagaan \\ Universiti Teknologi Mara \\ YAN-LING TAN \\ University Technology MARA \\ Johor Branch, Malaysia \\ CHIN-YU LEE \\ Faculty of Business and Finance \\ Universiti Tunku Abdul Rahman \\ LIM-THYE GOH \\ Faculty of Economic and Management \\ Universiti Putra Malaysia
}

\begin{abstract}
This paper aims to contribute to the existing literature by examining the dynamic relationship among petroleum consumption, financial development, economic growth and energy price. The sample of this study is based on the Malaysian annual data from 1980 to 2010. The model specification was examined in the Autoregressive Distributed Lag (ARDL) framework and the results revealed the existence of a long-run equilibrium. The findings indicated that financial development and economic growth cause a demand for energy to escalate in the long run. The Toda-Yamamoto (TYDL) non Granger-causality test provides evidence that there is unidirectional Granger-causality running from financial development and economic growth to energy consumption in the long run. This suggests that Malaysia is not an energy-dependent country. Hence, the government could implement energy conservation policies to reduce the waste of energy use. Given that development in the financial sector, and economic growth increase petroleum consumption in Malaysia, the policies pertaining to energy consumption should incorporate the development of the financial sector and economic growth of country.
\end{abstract}

Keywords: Petroleum consumption, financial development, non-renewable energy, Autoregressive Distributed Lag (ARDL), Toda-Yamamoto (TYDL) non Granger-causality test

Received: 24/11/2015 Revise: 27/09/2016 Accepted: 05/10/2016 Publish: 15/12/2016 


\section{Introduction}

Studies on the association between energy consumption and economic growth have been widely examined in the past decades. Indeed, energy can be classified into two types, namely renewable and non-renewable. Most of these studies focused on renewable energy such as electricity consumption ${ }^{1}$. On the contrary, the debate on non-renewable energy is not as extensive as renewable energy as in the investigation of the nexus between coal consumption and growth by Apergis and Payne (2010a) and Wolde-Rufael (2010), natural gas consumption and growth by Apergis and Payne (2010b), and fossil fuel-growth nexus by Ishida (2013). Petroleum, one of the non-renewable resources, is categorized as fossil fuel that neither can be reproduced nor generated. According to the U.S. Energy Information Administration (2011), the liquid's share of the world marketed energy consumption was 34 per cent in 2008 and will be reduced to 29 per cent in 2035. Liquid fuel, the most petroleum-based, nonetheless, still remains as the largest source of energy. Besides, liquid fuel is an important energy source in the transportation and industrial sector processes. Despite the rising fuel prices, the use of liquids for transportation increased by an average of 1.4 per cent in a year, or 46 per cent overall from 2008 to 2035 (U.S. Energy Information Administration, 2011). The transportation sector accounts for 82 per cent of the total increase in liquid fuel use from 2008 to 2035 while the remaining portion of the growth is attributable to the industrial sector.

In Malaysia, oil production stood at 862,000 barrels per day in 2004 and declined to 630,000 barrels per day in 2011, of which 83 per cent was crude oil, due to the maturity of the reservoirs (U.S. Energy Information Administration, 2011). This percentage will keep decreasing if there is no new discovery or new technology to increase the production from the existing fields. Ong, Mahlia and Masjuki (2012) commented that Malaysia's oil reserves will be exhausted in 21 years if the production rate is consistent at 700,000 barrels per day. Thus, studies on non-renewable energy are essential to some extent. On the one hand, the relationship between energy consumption and financial development was highlighted in recent studies by Shahbaz and Lean (2012), Islam, Shahbaz, Ahmed and Alam (2013), and Coban and Topcu (2013). Financial development affects energy consumption in two ways. Financial markets boost up energy use through industrial growth by creating more demand for new infrastructures (Islam et al., 2013). Likewise, financial development could also reduce 
energy consumption through the efficient use of energy (Islam et al., 2013; Mielnik \& Goldemberg, 2002). Given that the relationship between energy consumption and financial development was newly introduced with limited empirical evidences, this motivates us to fill the research gap by employing non-renewable energy, in particular petroleum consumption, and financial development.

The aim of this study is to investigate the long-run association among petroleum consumption, financial development, economic growth, and energy price in Malaysia, spanning from 1980 to 2010. This paper differs from existing works in several ways. First, we focused on non-renewable energy in comparison to renewable energy that has been intensively used. Second, in the context of energy use and financial development, we employed a more specific variable for non-renewable energy, which is petroleum consumption, instead of energy use in kilogram of oil equivalent per capita which is commonly examined in the prevailing literature. In addition, petroleum is also a major source of energy. Third, in the methodology, we estimated the long-run relationship by using the ARDL framework which is more appropriate for a small sample size as in this study. We used TodaYamamoto (TYDL) approach in examining the Granger-causality pattern of the variables in the system. The advantage of the TYDL is that it does not require each variable to be integrated in the same order. This goodness is applied to ARDL as well. Fourth, this study was based on a single-country sample that has some implications in designing related policies, particularly when Malaysia is one of the oil-exporting countries.

Following is the structure of this paper. In section 2, we provide some reviews on the theoretical and empirical studies. The data and model specification are presented in section 3 . Section 4 reports the empirical results. Finally, the conclusion and policy implications are discussed in section 5 .

\section{Literature Review}

The theoretical and empirical literatures on the nexus between energy consumption and economic growth have long been discussed substantially over the past decades. From the theoretical point of view, the energy consumption-growth nexus can be categorized into four well-established hypotheses. These hypotheses are growth, conservation, feedback and neutrality (Apergis \& Payne, 2010b; 
Apergis \& Payne, 2011a \& 2011b; Lean \& Smyth, 2010a \& 2010b). The growth hypothesis suggests that energy consumption has a significant impact on economic growth. Alternatively, the conservation hypothesis exists if there is unidirectional causality running from economic growth to energy consumption. The feedback hypothesis asserts the interdependent connection between energy consumption and economic growth, implying bidirectional causality between these two variables in either direction. Lastly, the non-existence of causality between energy and growth is in line with the neutrality hypothesis where energy consumption has little impact or no impact on economic growth.

A growing body of empirical studies examines the relationship between energy consumption, in particular renewable energy, and economic growth (Apergis \& Payne, 2011b; Chandran, Sharma \& Madhavan, 2010; Golam Ahamad \& Nazrul Islam, 2011; Lean \& Smyth, 2010a, 2010b). Yet there exists comparatively little work that investigates the non-renewable energy and growth nexus. For instance, non-renewable energy consumption includes coal (Apergis \& Payne, 2010a; Wolde-Rufael, 2010), natural gas (Apergis \& Payne, 2010b), fossil fuel (Ishida, 2013), and oil (Asafu-Adjaye, 2000). In the study of Apergis and Payne (2010a), the empirical evidence revealed that there was bidirectional causality between coal consumption and growth in 15 emerging market economies from 1980 to 2006 in both the short run and the long run. Similarly, Wolde-Rufael (2010) also found a bidirectional causality running between coal consumption and growth in South Africa and the United States between 1965 and 2005. In the meantime, a unidirectional causality running from coal consumption to growth was identified in India and Japan while causality running from grow th to coal consumption was found in China and South Korea. Besides, bidirectional causality between natural gas consumption and economic growth was discovered in 67 countries from 1992 to 2005 (Apergis \& Payne, 2010b). The findings of Ishida (2013) also pointed out that fossil fuel and growth depict bidirectional causality in Japan. On the other hand, Asafu-Adjaye (2000) found mixed results in Asian developing economies. The findings showed that there was bidirectional causality between oil consumption and economic growth in Thailand and the Philippines, while there was unidirectional causality running from oil consumption to growth in India and Indonesia in the short run.

To date, some studies have shifted towards exploring the causation between energy use and financial development. Financial development 
is particularly important because it is claimed to improve economic efficiency of the financial system (Sadorsky, 2010). The Theoretical literature suggests that a well-developed financial market can affect energy consumption through three channels (Sadorsky, 2011). These channels are named direct effect, business effect, and wealth effect. In direct effect, financial development helps consumers to access credit facilities more easily in purchasing consumer goods such as automobiles, houses, and home appliances which consume large amounts of energy. Improved financial sector also benefits the businessess where financial capital can be obtained easily at a lower cost for business expansions. Thus, energy use will be stimulted following the expansion in business units. Stock market development, on the one hand, influences businesses as it provides extra sources of funding and equity financing in expanding the existing business that boosts the demand for energy. An increase in stock market activity will create a wealth effect where it affects the confidence level of consumers and businesses. Subsequently, high economic confidence contributes to greater demand for energy in propelling growth. Besides, financial sector development benefits industrial growth as well by creating demands for new infrastructures, hence boosting the energy use (Islam et al., 2013). Contrary to the positive impacts of financial development on energy use, financial development may reduce energy consumption through the efficient use of energy (Islam et al., 2013; Mielnik \& Goldemberg, 2002).

Despite the importance of financial development in energy economics, empirical evidences that account for the effect of financial development is relatively scarce. Sadorsky (2010) investigated the causal linkage between financial development and energy consumption in 22 emerging countries in a period of study which ranged from 1990 to 2006. The results obtained revealed that financial development and energy consumption were positively associated. The positive relationship between financial development and energy consumption was also found in 9 Central and Eastern European (CEE) economies over the period 1996-2006 (Sadorsky, 2011). Almulali and Sab (2012a, 2012b) concluded that energy consumption increases financial development and economic growth in 19 selected countries and 30 Sub-Saharan African countries. Likewise, Coban and Topcu (2013) found that financial development has no significant impact on energy use in EU. Nevertheless, financial development affects energy consumption positively in EU's old members. Turning to single-country experience, the empirical findings of Shahbaz and Lean (2012) indicated the presence of long-run bidirectional causality 
between energy demand and financial development in Tunisia from 1971 to 2008.Ozturk and Acaravci (2013) pointed out that there was a short-run unidirectional causal linkage from financial development to energy use in Turkey. On the other hand, Tan and Tang (2012), with a period of study that ranged from 1972 to 2009, found that energy consumption Granger causes financial development in Malaysia. This implies that energy is an essential input for financial sector development (Islam et al., 2013). Another evidence from Malaysia claimed that financial development and economic growth affected energy consumption significantly from 1971 to 2009. Furthermore, evidence suggests that financial development could reduce energy use by enhancing energy efficiency.

\section{Model Specification and Methodology}

The model specification in this study was modified from the empirical work of Islam et al. (2013). We focused on petroleum consumption to reflect the extent of energy resources which Malaysia relies on, instead of aggregate energy data as performed by Islam et al. (2013) which added little value to policy makers. The regression equation in this study is written as:

$$
\ln P E T_{t}=\alpha_{0}+\beta_{1} F D_{t}+\beta_{2} \ln G D P_{t}+\beta_{3} \ln E P_{t}+\varepsilon_{t}
$$

where $\alpha$ is the intercept, $\beta_{1^{\prime}} \beta_{2^{\prime}}$ and $\beta_{3}$ are the coefficients to be estimated, $t$ denotes time period, and $\varepsilon_{t}$ is error-term. PET denotes petroleum consumption in a thousand barrels per day to represent non-renewable energy. FD is financial development which is measured by the domestic credit to the private sector in the per cent of GDP. GDP represents economic growth, and EP is energy price which is measured by the consumer price index (CPI). All variables are expressed in natural logarithm except FD. The data spanned from 1980 to 2010 for Malaysia and has collected from the World Development Indicator (WDI) and the U. S. Energy Information Administration (EIA). We postulate financial development and energy consumption are positively associated. A developed financial market stimulates investment and economic activities through two platforms (Minier, 2009; Sadorsky, 2010). The first platform is level effect. As financial market develops, the amount of funds available for investment also increases. This in turn promotes regulations to that practice better accounting and reporting systems which are crucial in gaining investors' confidence (Sadorsky, 2010; Shahbaz \& Lean, 
2012). The second platform is efficiency effect. Financial development enhances liquidity and asset diversification which directs investment to going to a higher return and high risk projects (Sadorsky, 2010). Therefore, financial development generates greater investment, economic growth, and energy use. On the other hand, we expect that economic growth and energy consumption are positively correlated. High economic growth promotes industrialization and greater business activities that induce greater use of energy (Halicioglu, 2007; Shahbaz \& Lean, 2012). The expected sign for energy price is negative based on the energy demand function (Halicioglu, 2007).

\section{Unit Root Test and Cointegration}

Prior to estimating the regression, we first conducted the unit root test on each of the variables using both the augmented Dickey Fuller (ADF) unit root rest (Dicky \& Fuller, 1979) and the Philips-Perror (PP) unit root test (Philips \& Perron, 1988) to determine the order of integration. Both tests were employed to obtain the robustness of the result. After determining the order of integration, we examined the presence of the long-run relation or cointegration among the variables by applying the autoregressive distributed lag (ARDL) bound testing (Pesaran, Shin \& Smith, 2001). The ARDL bound test is favorable for small sample properties and applicable for series with the mixed $\mathrm{I}(0)$ and I(1). Nonetheless, it requires the dependent variable to be I(1) while the independent variables can either be I(0) or I(1). Establishing the long-run equilibrium relationship in the ARDL framework, involves estimating the unrestricted error correction model (UECM) in the following form:

$$
\begin{aligned}
\Delta P E T_{t}= & \phi_{0}+\theta_{1} P E T_{t-1}+\theta_{2} F D_{t-1}+\theta_{3} G D P_{t-1}+\theta_{4} E P_{t-1} \\
& +\sum_{i=1}^{n} \gamma_{1 i} \Delta P E T_{t-i}+\sum_{i=0}^{n} \gamma_{2 i} \Delta F D_{t-i}+\sum_{i=0}^{n} \gamma_{3 i} \Delta G D P_{t-i}+\sum_{i=0}^{n} \gamma_{4 i} \Delta E P_{t-i}+\varepsilon_{1 t} \\
\Delta F D_{t}= & \psi_{0}+\theta_{1} F D_{t-1}+\theta_{2} P E T_{t-1}+\theta_{3} G D P_{t-1}+\theta_{4} E P_{t-1} \\
& +\sum_{i=1}^{k} \delta_{1 i} \Delta F D_{t-i}+\sum_{i=0}^{k} \delta_{2 i} \Delta P E T_{t-i}+\sum_{i=0}^{k} \delta_{3 i} \Delta G D P_{t-i}+\sum_{i=0}^{k} \delta_{4 i} \Delta E P_{t-i}+\varepsilon_{2 t}
\end{aligned}
$$




$$
\begin{aligned}
\Delta G D P_{t}= & \alpha_{0}+\theta_{1} G D P_{t-1}+\theta_{2} P E T_{t-1}+\theta_{3} F D_{t-1}+\theta_{4} E P_{t-1} \\
& +\sum_{i=1}^{m} \pi_{1 i} \Delta G D P_{t-i}+\sum_{i=0}^{m} \pi_{2 i} \Delta P E T_{t-i}+\sum_{i=0}^{m} \pi_{3 i} \Delta F D_{t-i}+\sum_{i=0}^{m} \pi_{4 i} \Delta E P_{t-i}+\varepsilon_{3 t}
\end{aligned}
$$

$$
\begin{aligned}
\Delta E P_{t}= & \varphi_{0}+\theta_{1} E P_{t-1}+\theta_{2} P E T_{t-1}+\theta_{3} F D_{t-1}+\theta_{4} G D P_{t-1} \\
& +\sum_{i=1}^{q} \Omega_{1 i} \Delta E P_{t-i}+\sum_{i=0}^{q} \Omega_{2 i} \Delta P E T_{t-i}+\sum_{i=0}^{q} \Omega_{3 i} \Delta F D_{t-i}+\sum_{i=0}^{q} \Omega_{4 i} \Delta G D P_{t-i}+\varepsilon_{4 t}
\end{aligned}
$$

where $\Delta$ is the first difference operator and $\varepsilon_{\mathrm{t}}$ is disturbance. The $F$-test statistic is used to ascertain the existence the long-run relationship by examining the lagged level of variables. The null hypothesis of no cointegration is set as Ho: $\theta_{1}=\theta_{2}=\theta_{3}=\theta_{4}=\theta$ against $H_{1}: \theta_{1} \neq \theta_{2} \neq \theta_{3}$ $\neq \theta_{4} \neq \theta$. The computed $F$-test statistic under the null hypothesis of no cointegration are expressed as F(PET|FD, GDP, INF), F(FD|PET, GNP, INF), F(DGP|PET, FD, INF), and F(INF|PET, FD, GDP) and for each equation, correspondingly.

The asymptotic distribution of $F$-statistics is non-standard as it relies on whether the underlying variables are $\mathrm{I}(0)$ or $\mathrm{I}(1)$, the number of independent variables, and whether the intercept and /or a trend is included in the ARDL model. Based on this ground, Pesaran et al. (2001) provided two sets of critical values where the first set assumes the variables to be $\mathrm{I}(0)$ that is known as the lower bound critical values and the other as I(1) which is called the upper bound critical values. Given that the critical values generated by Pesaran et al. (2001) are based on a large sample size ranging between 500 to 1000 observations, Narayan (2005) computed another set of critical values for a small sample size with 30 to 80 observations. In this study, therefore, we used Narayan's (2005) critical values as the sample size covering only 30 observations. If the computed F-statistics exceeds the upper bound critical value, we reject the null hypothesis and conclude that cointegration exists. If the computed F-statistics is below the lower bound critical value, we fail to reject the null hypothesis which implies no cointegration. If the computed $F$-statistics falls within the upper and lower bound critical values, then the cointegration test is inconclusive. 


\section{Granger-Causality}

We used the Toda-Yamamoto (1995) approach in examining the Granger-causality pattern of variables in the system. Toda-Yamamoto (1995) developed a modified Wald-test (MWALD) which allowed us to conduct the long-run causality test that does not require the same order of integration and cointegration properties. However, we performed the unit root test to gauge the knowledge of the maximal order of integration $\left(d_{\max }\right)$ for the corresponding variables in the system. The maximal order of integration $\left(d_{\max }\right)$ was then augmented in VAR order and was estimated as $k+d_{\max }$ where $k$ is optimal lag length that was determined by the Schwarz Bayesian Criteria (SBC). In estimating the augmented VAR $\left(k+d_{\max }\right)$ model, we put $d_{\max }=1$ as it performs better than other orders of $d_{\max }$ (Dolado \& Lütkepohl, 1996). Furthermore, to capture the direction of causality, we considered only the first $k$ VAR coefficient matrix and disregarded the coefficients of the last lagged $d_{\max }$ vector (Caporale \& Pittis, 1999). Following is the matrix to be estimated in the augmented VAR model:

$$
\begin{aligned}
& {\left[\begin{array}{c}
P E T_{t} \\
F D_{t} \\
G D P_{t} \\
E P_{t}
\end{array}\right]=\left[\begin{array}{c}
\alpha_{1} \\
\alpha_{2} \\
\alpha_{3} \\
\alpha_{4}
\end{array}\right]+\left[\begin{array}{llll}
\beta_{11,1} & \beta_{12,1} & \beta_{13,1} & \beta_{14,1} \\
\beta_{21,1} & \beta_{22,1} & \beta_{23,1} & \beta_{24,1} \\
\beta_{31,1} & \beta_{32,1} & \beta_{33,1} & \beta_{34,1} \\
\beta_{41,1} & \beta_{42,1} & \beta_{43,1} & \beta_{44,1}
\end{array}\right]\left[\begin{array}{c}
P E T_{t-1} \\
F D_{t-1} \\
G D P_{t-1} \\
E P_{t-1}
\end{array}\right]} \\
& +\ldots+\left[\begin{array}{llll}
\beta_{11, k} & \beta_{12, k} & \beta_{13, k} & \beta_{14, k} \\
\beta_{21, k} & \beta_{22, k} & \beta_{23, k} & \beta_{24, k} \\
\beta_{31, k} & \beta_{32, k} & \beta_{33, k} & \beta_{34, k} \\
\beta_{41, k} & \beta_{42, k} & \beta_{43, k} & \beta_{44, k}
\end{array}\right]\left[\begin{array}{c}
P E T_{t-k} \\
F D_{t-k} \\
G D P_{t-k} \\
E P_{t-k}
\end{array}\right] \\
& +\left[\begin{array}{lllll}
\beta_{11, q} & \beta_{12, q} & \beta_{13, q} & \beta_{14, q} \\
\beta_{21, q} & \beta_{22, q} & \beta_{23, q} & \beta_{24, q} \\
\beta_{31, q} & \beta_{32, q} & \beta_{33, q} & \beta_{34, q} \\
\beta_{41, q} & \beta_{42, q} & \beta_{43, q} & \beta_{44, q}
\end{array}\right]\left[\begin{array}{c}
P E T_{t-q} \\
F D_{t-q} \\
G D P_{t-q} \\
E P_{t-q}
\end{array}\right]+\left[\begin{array}{l}
\varepsilon_{1 t} \\
\varepsilon_{2 t} \\
\varepsilon_{3 t} \\
\varepsilon_{4 t}
\end{array}\right]
\end{aligned}
$$

where $k$ is order of lag length and $q$ is order of $\left(k+d_{\max }\right)$. We set the hypothesis of causality direction as:

$$
H o_{1}: \beta_{12,1}=\beta_{12,2}=\ldots=\beta_{12, k}=0, \begin{aligned}
& \text { indicating } F D \text { does not Granger } \\
& \text { cause PET. }
\end{aligned}
$$




$$
\begin{aligned}
& H o_{2}: \beta_{21,1}=\beta_{21,2}=\ldots=\beta_{21, k}=0 \text {, indicating PET does not Granger } \\
& \text { cause } F D \text {. } \\
& H o_{3}: \beta_{13,1}=\beta_{13,2}=\ldots=\beta_{13, k}=0, \quad \text { indicating GDP does not Granger } \\
& \text { cause PET. } \\
& H o_{4}: \beta_{31,1}=\beta_{31,2}=\ldots=\beta_{31, k}=0, \quad \text { indicating PET does not Granger } \\
& \text { cause GDP. }
\end{aligned}
$$

and so on and so forth for the rest of variables.

\section{Results Discussion}

Conducting the unit root test is essential in analyzing time seriesbased macroeconomic variables to avoid spurious regression. Thus, augmented Dickey-Fuller (ADF) and Philip-Perron (PP) unit root tests were conducted to determine the order of integration. Specifically, all variables were examined at level and first difference with the inclusion of intercept and trend. The results of the unit root tests are reported in Table 1.

Table 1

The Results of Unit Root Tests

\begin{tabular}{lcccc}
\hline \multirow{2}{*}{ Variables } & \multicolumn{2}{c}{ Level } & \multicolumn{2}{c}{ First Difference } \\
\cline { 2 - 5 } & ADF & PP & ADF & PP \\
\hline PET & -0.728 & -1.207 & $-3.631^{* *}$ & $-3.627^{* *}$ \\
FD & -1.472 & -1.618 & $4.567^{* *}$ & $-4.524^{* *}$ \\
GDP & -1.165 & -1.379 & $-4.406^{* *}$ & $-4.414^{* *}$ \\
EP & -3.119 & $-3.318^{*}$ & $-4.799^{* *}$ & $-4.864^{* *}$ \\
\hline Note: & ** and ${ }^{*}$ denote $5 \%$ and $10 \%$ significance level, respectively. For ADF
\end{tabular}
test, SIC was used to select the optimal lag length.

The maximum number of lags is 7. For PP test, Barlett Kernel was used as the spectral estimation method.

Based on Table 1, all variables are statistically significant at first difference except $E P$ is significant at level in the PP test. Thus, the order of integration for $P E T, F D$, and GDP are $\mathrm{I}(1)$ while $E P$ is $\mathrm{I}(0)$. Hence, 
performing the ARDL bound test for cointegration was relevant as our data showed a mixture of I(0) and I(1) variables. The results of the cointegration bound tests are presented in Table 2 . The null hypothesis of no cointegration is rejected in 3 equations implying the presence of a long-run equilibrium relationship in the model. This indicates that these variables are tied together and any deviations among them will be adjusted back to the long-run equilibrium. When PET and FD are served as dependent variables, their calculated $F$-statistics 4.208 and 4.320 , respectively are beyond the upper bound critical values at $10 \%$ significance level (4.150). Similarly, cointegration was also found in the $E P$ equation where the generated $F$-statistics (5.456) was higher than the upper bound critical values at $5 \%$ significance level.

Table 2

Bound Test for Cointegration

Critical value bounds of the F-statistic: unrestricted intercept and no trend

\begin{tabular}{cccccccc}
\hline \multicolumn{3}{c}{$90 \%$ level } & \multicolumn{2}{c}{$95 \%$ level } & \multicolumn{2}{c}{$99 \%$ level } \\
$\mathrm{I}(0)$ & $\mathrm{I}(1)$ & $\mathrm{I}(0)$ & $\mathrm{I}(1)$ & $\mathrm{I}(0)$ & $\mathrm{I}(1)$ \\
3.008 & 4.150 & & 5.018 & 5.333 & 7.063
\end{tabular}

Cointegration

hypothesis

Calculated F-statistic

$F(P E T \mid F D, G D P, E P)$

$4.208^{*}$

$F(F D \mid P E T, G D P, E P)$

$4.320^{*}$

$F(G D P \mid P E T, F D, E P)$

2.673

$F(E P \mid P E T, F D, G D P)$

$5.456^{* *}$

Note: ${ }^{* *}$ and ${ }^{*}$ denote $5 \%$ and $10 \%$ significance level, respectively. The critical values are extracted from Narayan (2005), using Case III, number of regressors $(k)$ is 3 , number of observation $(n)$ is 30 .

Having found that the variables are cointegrated, we investigated the long-run coefficients of equation 1 using the ARDL $(p, q, s, r)$ specification: 
$P E T_{t}=\alpha_{0}+\sum_{i=1}^{p} \alpha_{1} P E T_{t-i}+\sum_{i=0}^{q} \alpha_{2} F D_{t-i}+\sum_{i=0}^{s} \alpha_{3} G D P_{t-i}+\sum_{i=0}^{r} \alpha_{3} E P_{t-i}+\mu_{t}$

The lag lengths $p, q, s, r$ were selected by the Schwarz Bayesian Criteria (SBC). Table 3 summarizes the results of the long-run elasticities. The results reveal that the effect of financial development on energy demand was positive which is consistent with previous studies such as Sadorsky (2010, 2011), Shahbaz and Lean (2012) and Islam et al. (2013). A 10 per cent increase in domestic credit to the private sector is anticipated to raise petroleum consumption by 0.02 per cent, ceteris paribus. This implies that development in the financial market enables businesses and consumers to have better access to credit facilities for investment and buying goods and services such as automobiles and home appliances that add to energy use. The coefficient of economic growth is 1.053 and it is significant at 5\% level. A 10 per cent rise in economic growth stimulates petroleum use by 10.53 per cent, ceteris paribus. This mirrors that economic growth enhances industrial output and improves the standard of living that lead to a greater demand for energy. This confirms earlier findings reported in Islam et al. (2013), Shazbaz and Lean (2012), Halicioglu (2007), Odhiambo (2009), Bowden and Payne (2009), Ang (2008), Altinay and Karagol (2005), Ghosh (2002), and Aqeel and Butt (2001) which claimed that economic growth has a positive impact on energy use. The diagnostic tests show that the model is well specified as the Ramsey RESET test failed to reject the null hypothesis of no specification error. Besides that, the residuals were not serially correlated and homoscedastic.

Table 3

ARDL (2, 1, 0, 2) Long-run Estimates

\begin{tabular}{lccc}
\hline Dependent variable: PET & & & \\
\hline Regressor & Coefficients & t-statistics & $p$-values \\
FD $_{\mathrm{t}}$ & $0.002^{* * *}$ & 5.204 & 0.000 \\
$\mathrm{GDP}_{\mathrm{t}}$ & $1.053^{* *}$ & 3.752 & 0.001 \\
$\mathrm{EP}_{\mathrm{t}}$ & -0.697 & 1.128 & 0.273 \\
Constant & -19.079 & -4.107 & 0.001 \\
R-Bar-Square $=0.995$ & & & \\
DW-Statistic $=2.354$ & & & \\
S.E. of Regression $=0.026$ & & & \\
\hline
\end{tabular}

(continued) 
IJMS 23 (2), 27-44 (2016)

\begin{tabular}{llll}
\hline Dependent variable: PET $_{+}$ & & & \\
\hline Regressor & Coefficients & $t$-statistics & $p$-values \\
Diagnostic Test & & & \\
\hline
\end{tabular}

Serial Correlation: $\mathrm{F}(1,18)=1.3430[.262]$

Functional Form: $\mathrm{F}(1,18)=2.8155$ [.111]

Heteroscedasticity: F $(1,26)=0.15414$ [.698]

Note: ${ }^{* *}$ and ${ }^{* *}$ denote $1 \%$ and $5 \%$ significance level, respectively.

To ensure that our results are robust, we performed the CUSUM and the CUSUM square stability tests as shown in Figure 1a and Figure $1 \mathrm{~b}$, respectively. The plots of CUSUM and CUSUMSQ for the model lie within the critical bounds of 5\% significance level. This indicates that the coefficients in the model are stable and free from structural break over the sample period.
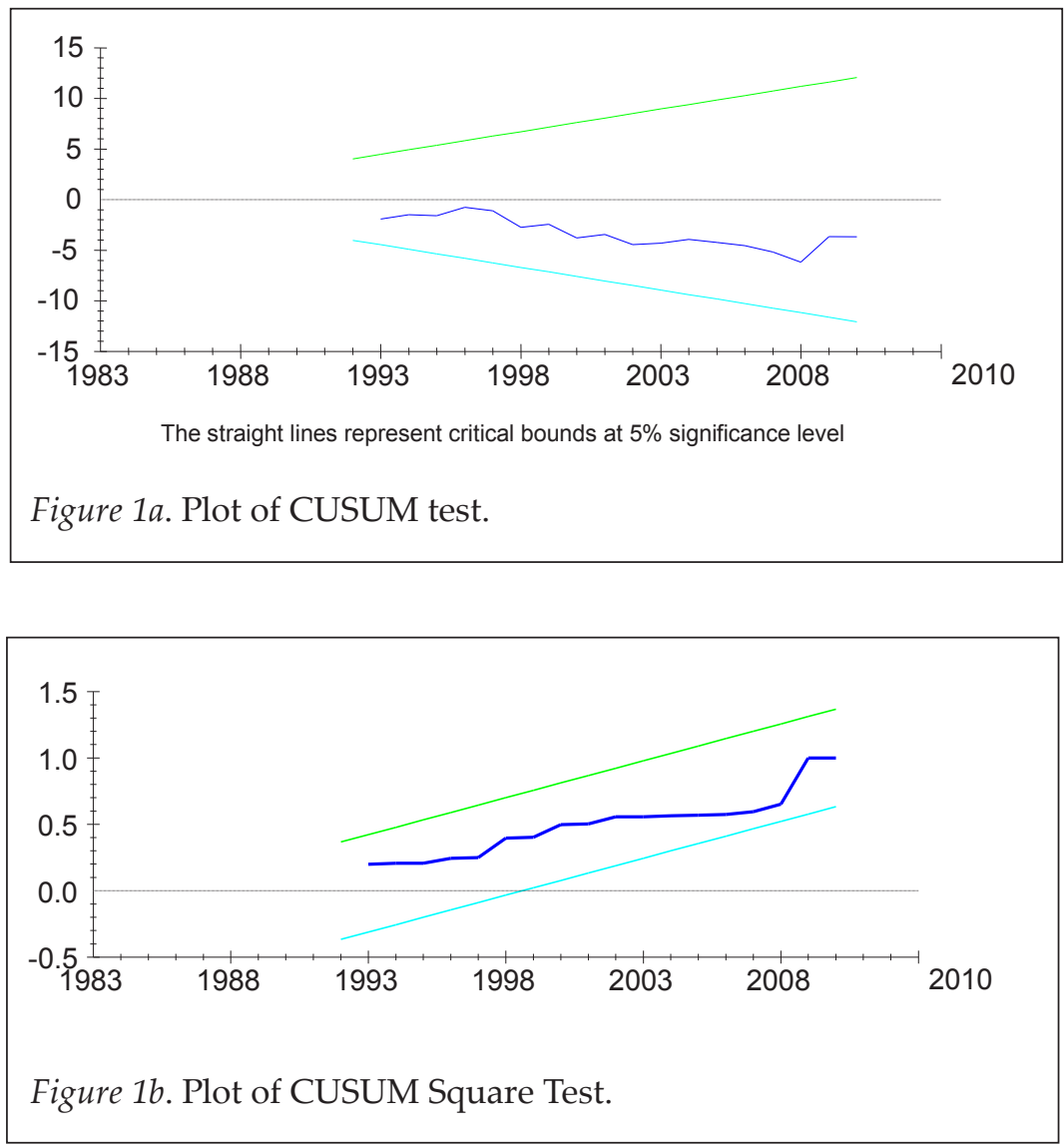
IJMS 23 (2), 27-44 (2016)

Table 5

Toda-Yamamoto non Granger-causality Test ( $\chi^{2}$ statistics)

\begin{tabular}{|c|c|c|c|c|}
\hline \multirow{2}{*}{ Effect } & \multirow[b]{2}{*}{$\mathrm{PET}_{\mathrm{t}}$} & \multicolumn{2}{|c|}{ Cause } & \multirow[b]{2}{*}{$\mathrm{EP}_{\mathrm{t}}$} \\
\hline & & $\mathrm{FD}_{\mathrm{t}}$ & $\mathrm{GDP}_{\mathrm{t}}$ & \\
\hline $\mathrm{PET}_{t}$ & - & $3.778^{*}(0.052)$ & $7.629^{* *}(0.006)$ & $2.227(0.136)$ \\
\hline $\mathrm{FD}_{\mathrm{t}}$ & $0.155(0.694)$ & - & $0.022(0.881)$ & $2.333(0.127)$ \\
\hline $\mathrm{GDP}_{\mathrm{t}}$ & $1.474(0.225)$ & $0.298(0.585)$ & - & $0.073(0.788)$ \\
\hline $\mathrm{EP}_{\mathrm{t}}$ & $2.228(0.136)$ & $1.960(0.162)$ & $0.559(0.455)$ & - \\
\hline
\end{tabular}

\section{Conclusion}

The nexus between energy consumption and economic growth has been discussed substantially over the past decades. This paper attempts to add knowledge to the existing literature by examining the dynamic association among petroleum consumption, financial development, economic growth and energy price. The sample of this study was based on the Malaysian annual data from 1980 to 2010. In view of the finite sample size, this study applied the ARDL bound testing to examine the presence of cointegration and long-run coefficients of variables in the multivariate framework. The results of the ARDL bound testing confirmed that the underlying variables were cointegrated, indicating that these variables were moving together in the long run. From the aspect of long-run relations, we found out that financial development and economic growth positively affect petroleum consumption in Malaysia. Development in the financial sector provides a platform for consumers and businesses to access low-cost credit facilities to purchase motor vehicles which would lead to a greater demand for petroleum consumption. At the same time, increases in economic growth improve the standard of living and purchasing power to purchase motor vehicles that cause petroleum consumption to escalate.

Besides that, the Toda-Yamamoto Granger-causality test indicated that there was unidirectional Granger-causality running from financial 
development and economic growth to petroleum consumption in the long run. This suggests that Malaysia is not a petroleum dependent country. Hence, the government could implement petrol conservation policies to reduce the use of petroleum and replace it with other non-petroleum based fuel. On the other hand, given that financial development and economic growth increase petroleum consumption in Malaysia, policies pertaining to petroleum consumption should incorporate the development of the financial sector and the economic growth of the country. The policy implication of this study is that it initiates policy-makers' interest to formulate strategies to increase petroleum production and inventory. This can be probably achieved through discovering new oil fields or negotiating new long-term supply contracts to support the rising demand for petroleum. At the same time, the government could introduce petrol conservation policies through financial development that promotes efficient petroleum use by investing in new petrol-saving technology.

\section{End Notes}

1 For instance, the electricity consumption-growth nexus in Malaysia (Chandran et al., 2010; Lean \& Smyth, 2010b; Tang, 2008); in Korea (Yoo, 2005); in China (Yuan et al., 2007); in Africa (Wolde-Rufael, 2006); in ASEAN (Yoo, 2006); and in OPEC (Squalli, 2006).

\section{References}

Al-mulali, U., \& Sab, C.N.B.C. (2012a). The impact of energy consumption and $\mathrm{CO} 2$ emissions on the economic and financial development in 19 selected countries. Renew. Sustain. Energy Rev., 16, 4365-4369.

Al-mulali, U., \& Sab, C.N.B.C. (2012b). The impact of energy consumption and $\mathrm{CO} 2$ emissions on the economic growth and financial development in the Sub Saharan African countries. Energy, 39, 180-186.

Altinay, G., \& Karagol, E. (2005). Electricity consumption and economic growth: Evidence from Turkey. Energy Economics, 27, 849-856.

Ang, J. B. (2008). Economic development, pollutant emissions and energy consumption in Malaysia. Journal of Policy Modeling, 30, 271-278. 
Apergis, N., \& Payne, J. E. (2010a). The causal dynamics between coal consumption and growth: Evidence from emerging market economies. Applied Energy, 87, 1972-1977.

Apergis, N., \& Payne, J. E. (2010b). Natural gas consumption and economic growth: A panel investigation of 67 countries. Applied Energy, 87, 2759-2763.

Apergis, N., \& Payne, J. E. (2011a). Renewable and non-renewable electricity consumption-growth nexus: Evidence from emerging market economies. Applied Energy, 88, 5226-5230.

Apergis, N., \& Payne, J. E. (2011b). The renewableenergy consumptiongrowth nexus in Central America. Applied Energy, 88, 343-347.

Aqeel, A., \& Butt, M.S. (2001). The relationship between energy consumption and economic growth in Tunisia. Asia-Pacific Development Journal, 8, 101-110.

Asafu-Adjaye, J. (2000). The relationship between energy consumption, energy prices and economic growth: Time series evidence from Asian developing countries. Energy Economics, 22, 615-625.

Bowden, N., \& Payne, J.E. (2009). The causal relationship between US energy consumption and real output: A disaggregated analysis. Journal of Policy Modeling, 31, 180-188.

Caporale, G. M., \& Pittis, N. (1999). Efficient estimation of of cointegrating vectors and testing for causality in vector autoregressions. Journal of Economic Issues, 13, 3-35.

Chandran, V.G.R., Sharma, S., \& Madhavan, K. (Tiada surname). (2010). Electricity consumption-growth nexus: The case of Malaysia. Energy Policy, 38, 606-612.

Chor Foon Tang, \& Bee Wah Tan. (2012). The linkages among energy consumption, economic growth, relative price, foreign direct investment, and financial development in Malaysia. Quality and Quantity, 48(2), 781-797. http://dx.doi.org/10.1007/s11135012-9802-4.

Coban, S., \& Topcu, M. (2013). The nexus between financial development and energy consumption in the EU: A dynamic panel data analysis. Energy Economics, 39, 81-88.

Dickey, D. A., \& Fuller, W. A. (1979). Distributions of the estimators for autoregressive time series with a unit root. Journal of American Association, 74, 427-431.

Dolado, J. J., \& Lütkepohl, H. (1996). Making wald tests work for cointegrated VAR systems. Econometric Reviews, 15, 369-386.

Ghosh, S. (2002). Electricity consumption and economic growth in India. Energy Policy, 30, 125-129. 
Golam Ahamad, M., \& Nazrul Islam, A. K. M. (2011). Electricity consumption and economic growth nexus in Bangladesh: Revisited evidences. Energy Policy, 39, 6145-6150.

Halicioglu, F. (2007). Residential electricity demand dynamics in Turkey. Energy Economics, 29, 199-210.

Ishida, H. (2013). Causal relationship between fossil fuel consumption and economic growth in Japan: A multivariate approach. International Journal of Energy Economics and Policy, 3, 127-136.

Islam, F., Shahbaz, M., Ahmed, A. U., \& Alam, M. M. (2013). Financial development and energy consumption nexus in Malaysia: A multivariate time series analysis. Economic Modelling, 30, 435441.

Lean, H. H., \& Smyth, R. (2010a). Multivariate Granger causality between electricity generation, exports, prices and GDP in Malaysia. Energy, 35, 3640-3648.

Lean, H. H., \& Smyth, R. (2010b). On the dynamics of aggregate output, electricity consumption and exports in Malaysia: Evidence from multivariate granger causality tests. Applied Energy, 87, 1963-1971.

Mielnik, O., \& Goldemberg, J. (2002). Foreign direct investment and decoupling between energy and gross domestic product in developing countries. Energy Policy, 30, 87-89.

Minier, J. (2009). Opening a stock exchange. Journal of Development Economics, 90, 135-143.

Narayan, P. K. (2005). The saving and investment nexus for China: Evidence from cointegration tests. Applied Economics, 37, 19791990.

Odhiambo, N.M. (2009). Energy consumption and economic growth nexus in Tanzania: An ARDL bounds testing approach. Energy Policy, 37, 617-622.

Ong, H.C., Mahlia, T.M., \& Masjuki, H.H. (2012). A review on energy pattern and policy for transportation sector in Malaysia. Renewable and Sustainable Energy Reviews, 16, 532- 542.

Ozturk, I., \& Acaravci, A. (2013). The long run and causal analysis of energy, growth, openness and financial development on carbon emissions in Turkey. Energy Economics, 36, 262-267.

Pesaran, M. H., Shin, Y., \& Smith, R. (2001). Bounds testing approaches to the analysis of level relationship. Journal of Applied Econometrics, 16, 289-326.

Philips, P. C. B., \& P. Perron (1988). Testing for a unit root in time series regressions. Biometrika, 75, 335-346. 
IJMS 23 (2), 27-44 (2016)

Sadorsky, P. (2010). The impact of financial development on energy consumption in emerging economies. Energy Policy, 38, 25282535.

Sadorsky, P. (2011). Financial development and energy consumption in Central and Eastern European frontier economies. Energy Policy, 39, 999-1006.

Shahbaz, M., \& Lean, H. H. (2012). Does financial development increase energy consumption? The role of industrialization and urbanization in Tunisia. Energy Policy, 40, 473-479.

Squalli, J. (2006). Electricity consumption and economic growth: Bounds and causality analyses of OPEC members. Energy Economics, 29, 1192-1205.

Tang, C.F. (2008). A re-examination of the relationship between electricity consumption and economic growth in Malaysia. Energy Policy, 36, 3077-3085.

Toda, H. Y., \& Yamamoto, T. (1995). Statistical inference in vector autoregressions with possibly integrated processes. Journal of Econometrics, 66, 225-250.

U.S. Energy Information Administration (2011). International energy outlook 2011. Washington D. C: Energy Information Adminstration.

Wolde-Rufael, Y. (2006). Electricity consumption and economic growth: A time series experience for 17 African countries. Energy Policy, 34, 1106-1114.

Wolde-Rufael, Y. (2010). Coal consumption and economic growth revisited. Applied Energy, 87, 160-167.

Yoo, S. H. (2005). Electricity consumption and economic growth: Evidence from Korea. Energy Policy, 33, 1627-1632.

Yoo, S. H. (2006). The causal relationship between electricity consumption and economic growth in the ASEAN countries. Energy Policy, 34, 3573-3582.

Yuan, J., Zhao, C., Yu, S., \& Hu, Z. (2007). Electricity consumption and economic growth in China: Cointegration and co-feature analysis. Energy Economics, 29, 1179-1191.

Zapata, H. O., \& Rambaldi, A.N. (1997). Monte Carlo evidence on cointegration and causation. Oxford Bulletin of Economics and Statistics, 59(2), 285-298. 